\title{
Behaviour of Reinforced Concrete Beams with Circular Transverse Openings under Static Loads
}

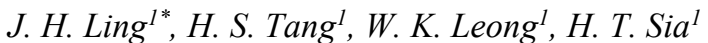 \\ ${ }^{I}$ School of Engineering and Technology, University College of Technology Sarawak, 96000 Sibu, Sarawak, Malaysia \\ *Email: lingjenhua@ucts.edu.my
}

\begin{abstract}
Transverse opening in a reinforced concrete beam allows the crossing of mechanical and electrical services through the beam. However, it affects the strength of a beam. Understanding its structural behaviour is crucial to ensure a safe design of the beam. For that, an experimental study was carried out on reinforced concrete beams with circular transverse openings. The four-point load test was conducted to study the effects of the size and the position of the opening on the beam performance under the shear and flexural loads. In addition, three reinforcing methods for the opening were tested. The beams were evaluated in terms of the load-displacement responses, mechanical properties, deflections, and failure modes. The opening with the diameter not exceeding 0.25 times beam height affected about $20 \%$ of beam strength (without reinforcements at the opening). The diagonal bar reinforcing method effectively restored the beam strength for the opening size not exceeding $1 / 3$ of beam height. The equation model proposed conservatively predicted the ultimate capacity of the beam with a transverse opening.
\end{abstract}

Keywords: Reinforced Concrete Beam, Circular Transverse Opening, Flexural and Shear Load Paper type: Research paper

\section{INTRODUCTION}

Transverse opening provides a passage for the mechanical and electrical services through a reinforced concrete (RC) beam when the ceiling space is insufficient. It reduces the required length of the services and the headroom of the building. With that, fewer loads are to be transferred to the foundations, and this reduces the building cost [1]. The cost savings could be substantial when it is repeatedly applied over a multi-story building or a large scale project [2].

The opening in RC beams have been extensively studied through experiments, numerical modelling and analytical derivation [3-6], (a) in various types of beam, such as simply supported beams [7-14], deep beams [1527], continuous beams [28, 29], cantilever beams [2, 30], T-beams [31-36], curved beams [37-39] and etc, and (b) subjected to various types of load, such as the flexural and shear loads [18, 40-44], torsional load [45, 46], impact load [31], and seismic load [2,30].

The opening affected the structural performance of a beam. The beams had lower strength and stiffness, endured excessive deflections, and demonstrated premature cracking and failure [2, 8, 31, 36, 47-49]. The opening caused a discontinuity of the cross-sectional configuration and led to the concentration of stress surrounding it [36]. This caused the beams to fail in poor ductility immediately after the diagonal shear cracks propagated through the opening [50]. The opening was more critically placed at the shear zone than the flexural zone of the beam [41].

The opening is considered small when the beam-type behaviour is maintained, which means the beam theory is still applicable $[2,51]$. For a marginal strength reduction of the beam (not exceeding $10 \%$ ), the opening size should not exceed 0.25 or 0.2 times the beam's depth $[17,52$, ]. In rectangular shape, the opening height should not exceed 0.2 times the beam depth and the opening length should be limited to 0.05 times the beam length [53].

The beam strength was more severely affected by large opening size [50]. When the size increased from 0.3 to 0.5 times the beam height, a $51 \%$ average strength reduction was reported [50]. The beam reduced $75 \%$ capacity as the opening size reached 0.6 times the beam depth [54].

The opening can be in various shapes $[51,55]$. Circular openings are commonly used for the passage of service pipes, while rectangular openings are for air-conditioning ducts [51]. Beams with circular openings offer $8 \%$ higher strength than square openings [7, 10, 41]. The orthogonal corners attracted stress concentration, and this affected the beam strength $[41,46]$.

The opening is preferably placed at the upper corners of a deep beam, which is far from the arching action and the flexure region [16]. For the shallow beams, openings should avoid the regions with maximum displacement and shear [48].

Despite the numerous studies, the understanding of the beams with openings is still fragmented. For some reason, discrepancies of the findings by different researchers are observed. Some recommended the opening size not to exceed 0.2 to 0.25 times the beam depth [17, 52], while the others suggested 0.44 to $0.48[7,10]$. On top of 
that, the current design codes, such as ACI-318 [56], provide no explicit guide to design a beam with openings [2]. Engineers who are unconfident to design such beams tend to avoid it or provide very conservative designs.

This paper presents an experimental study to investigate the behaviour of RC beams with a circular opening. The purposes are (a) to investigate the effects of the size and position of the opening on beam's performance, and (b) to determine a suitable reinforcing method for the opening.

\section{METHOD}

\section{Specimen details}

Eleven RC beams were tested under the four-point load test (Fig. 1). This included (a) 2 control beams without opening, (b) 6 beams with openings, and (c) 3 beams with reinforced openings (Table I). The beam size was $150 \mathrm{~mm}$ (width) x $300 \mathrm{~mm}$ (height) x $1650 \mathrm{~mm}$ (length). The clear span between supports was $1500 \mathrm{~mm}$.
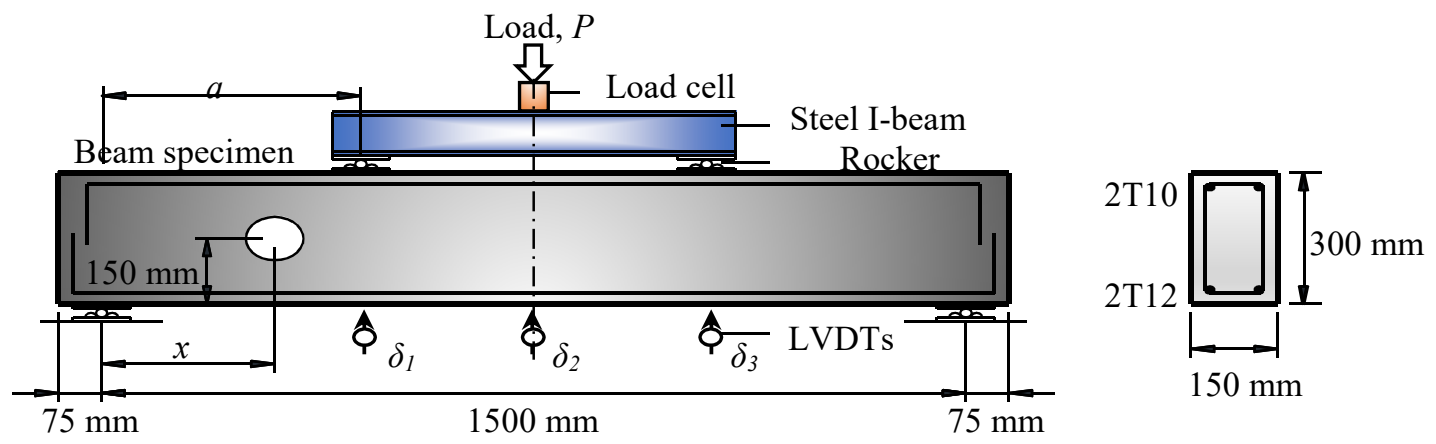

Fig. 1: Test setup

TABLE 1. SPECIMEN DETAILS

\begin{tabular}{|c|c|c|c|c|c|}
\hline \multirow[b]{2}{*}{ Specimen $^{\text {a }}$} & \multicolumn{2}{|c|}{ Transverse opening } & \multirow{2}{*}{$\begin{array}{c}\text { Point load } \\
\text { Distance from support, } \\
a(\mathrm{~mm}) \\
\end{array}$} & \multirow{2}{*}{$\begin{array}{l}\text { Shear } \\
\text { reinforcement }\end{array}$} & \multirow[b]{2}{*}{ Remarks } \\
\hline & $\begin{array}{c}\text { Diameter, } \\
d_{o}(\mathrm{~mm})\end{array}$ & $\begin{array}{c}\text { Distance from support, } \\
x(\mathrm{~mm})\end{array}$ & & & \\
\hline $\mathrm{C} 1 / \mathrm{S}$ & - & - & 500 & $\mathrm{R} 8-250$ & Control, shear \\
\hline $\mathrm{C} 2 / \mathrm{F}$ & - & - & 600 & $\mathrm{R} 8-150$ & $\begin{array}{l}\text { Control, } \\
\text { flexural }\end{array}$ \\
\hline $\mathrm{S} 1 / 100$ & 100 & 300 & 500 & $\mathrm{R} 8-250$ & Shear \\
\hline $\mathrm{S} 2 / 75$ & 75 & 300 & 500 & $\mathrm{R} 8-250$ & Shear \\
\hline $\mathrm{S} 3 / 50$ & 50 & 300 & 500 & $\mathrm{R} 8-250$ & Shear \\
\hline $\mathrm{F} 1 / 100$ & 100 & 750 & 600 & $\mathrm{R} 8-150$ & Flexural \\
\hline $\mathrm{F} 2 / 75$ & 75 & 750 & 600 & $\mathrm{R} 8-150$ & Flexural \\
\hline $\mathrm{F} 3 / 50$ & 50 & 750 & 600 & $\mathrm{R} 8-150$ & Flexural \\
\hline $\mathrm{R} 1 / \mathrm{DR}$ & 100 & 300 & 500 & $\mathrm{R} 8-250$ & $\begin{array}{l}\text { Shear, } \\
\text { reinforced }\end{array}$ \\
\hline R2/GI & 100 & 300 & 500 & $\mathrm{R} 8-250$ & $\begin{array}{l}\text { Shear, } \\
\text { reinforced }\end{array}$ \\
\hline R3DS & 100 & 300 & 500 & $\mathrm{R} 8-250$ & $\begin{array}{l}\text { Shear, } \\
\text { reinforced }\end{array}$ \\
\hline
\end{tabular}

${ }^{a} C$-control, $S$-shear, $F$-flexural, $R$-reinforcement to opening

All specimens were reinforced with 2T12 and 2T10 high yield steel bars $\left(f_{y, b}=460 \mathrm{~N} / \mathrm{mm}^{2}\right)$ as the bottom and top reinforcements, respectively. The shear links were R8-150 and R8-250 mild steel bars $\left(f_{y, s l}=250 \mathrm{~N} / \mathrm{mm}^{2}\right)$ for flexural and shear load tests, respectively. The concrete cover was $25 \mathrm{~mm}$.

The beam specimens were horizontally cast in plywood moulds. Ready-mixed concrete of grade 25 (maximum aggregate size $=20 \mathrm{~mm}$, designed slump $=60 \mathrm{~mm}$ to $180 \mathrm{~mm}$ ) was used. The specimens were cured for 7 days at an atmospheric temperature of $30 \pm 5^{\circ} \mathrm{C}$ and tested after 28 days of casting.

Polyvinyl Chloride (PVC) pipes (diameters, $d_{o}=50 \mathrm{~mm}, 75 \mathrm{~mm}$ and $100 \mathrm{~mm}$ ) were used to create the opening. It was placed at the midheight of the beam $(150 \mathrm{~mm}$ from soffit) and distance, $x$, from the support (Table 1 and Fig. 1). The opening was placed at the midspan and the support for the shear and flexural load tests, respectively. To encourage shear failure for the shear load test, the point loads were placed closer to the support $(a=500 \mathrm{~mm})$ and fewer shear links (R8-250) were provided. 
Three types of opening reinforcements were provided, namely the diagonal reinforcement, Galvanised Iron (G. I.) pipe and diagonal square reinforcement (Fig. 2). The diagonal reinforcement bars were placed at $25 \mathrm{~mm}$ offset distance from the opening and the G.I. pipe replaced the PVC pipe. The effectiveness of these reinforcement methods was evaluated.

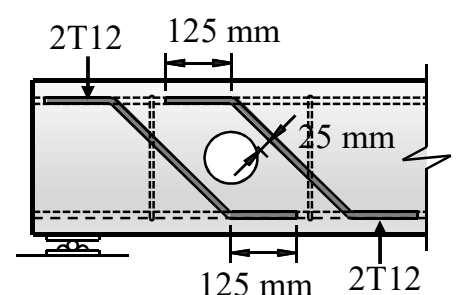

(a) R1/DR: Diagonal reinforcement

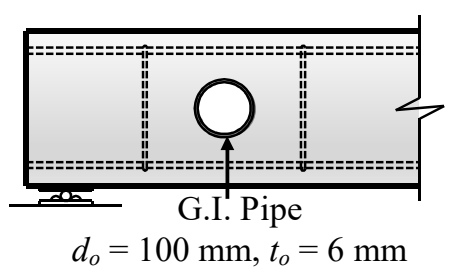

(b) R2/GI: G.I. Pipe reinforcement

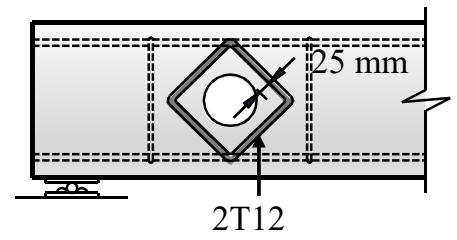

(c) R3/DS: Diagonal square reinforcement

Fig. 2: Reinforcing method for opening

\section{Test setup:}

A static load was applied on the beam by using a hydraulic cylinder (Fig. 3). The steel I-beam distributed the load into 2 point loads acting on the beam. The load cell placed between the hydraulic cylinder and the steel I-beam was used to measure the load. Three linear variable differential transducers (LVDT) were placed below the beam at the midspan and the point loads to measure the beam deflection. All measuring devices were connected to a data logger for data acquisition. The specifications of the instruments used are outlined in Table 2.

\section{TABLE 2. INSTRUMENT SPECIFICATIONS}

\begin{tabular}{llll}
\hline Instruments & Brand, Model & Description & $\begin{array}{l}\text { Data } \\
\text { accuracy }\end{array}$ \\
\hline $\begin{array}{l}\text { Hydraulic Cylinder } \\
\text { Hydraulic Pump }\end{array}$ & $\begin{array}{l}\text { Enerpac, RR-10018 } \\
\text { Enerpac P464 } \\
\begin{array}{l}\text { Displacement } \\
\text { transducer }\end{array}\end{array}$ & $\begin{array}{l}\text { Push +933 kN, Pull -435 kN } \\
\text { Manual hand pump }\end{array}$ & - \\
$\begin{array}{l}\text { Load Cell } \\
\text { Data Logger }\end{array}$ & TML, CLJ-300KNB & 100 mm & - \\
& TML, TDS-530 & 30 Channels & $0.01 \mathrm{~mm}$ \\
\end{tabular}



Fig. 3: Experimental setup in the laboratory

Test procedure:

Before the test started, all readings were set to zero. The beam was preloaded to $10 \%$ of the estimated beam capacity for 5 minutes to consolidate the test setup. The load was then released for another 5 minutes to observe the reading recovered to zero for the validity check of the measuring devices. This process was repeated twice.

Then, the readings were reinitialised to zero before the test started. The load increased at an interval of $7 \mathrm{kN}$ load or $0.5 \mathrm{~mm}$ deflection (whichever reached first) until the specimen failed. Readings were taken after holding the load for at least 1 minute. The load-displacement response of the beam and the propagation of cracks were monitored throughout the test. 


\section{TEST RESUlts}

\section{Material properties:}

The test results were considered acceptable based on the following justifications: (Tables 3 and 4)

a. The concrete strength, $f_{c, u}$, ranged from $24.7 \mathrm{~N} / \mathrm{mm}^{2}$ to $26.9 \mathrm{~N} / \mathrm{mm}^{2}$, which was close to the designed strength of $25 \mathrm{~N} / \mathrm{mm}^{2}$.

b. The bar strength was constantly higher than the specified yielding strength of $460 \mathrm{~N} / \mathrm{mm}^{2}$ and $250 \mathrm{~N} / \mathrm{mm}^{2}$ for the main bars and shear links, respectively.

c. The concrete density was quite consistent. It ranged between $2300 \mathrm{~kg} / \mathrm{m}^{3}$ and $2400 \mathrm{~kg} / \mathrm{m}^{3}$.

TABLE 3. TEST RESULTS OF CONCRETE CUBES REPRESENTING DIFFERENT TEST SPECIMENS

\begin{tabular}{cccc}
\hline $\begin{array}{c}\text { Testing } \\
\text { day }\end{array}$ & $\begin{array}{c}\text { Specimen } \\
\text { a }\end{array}$ & $\begin{array}{c}\text { Compressive } \\
\text { strength of cube, } \\
f_{c, u}\left(\mathrm{~N} / \mathrm{mm}^{2}\right)\end{array}$ & $\begin{array}{c}\text { Density } \\
\rho_{c} \\
\left(\mathrm{~kg} / \mathrm{m}^{3}\right)\end{array}$ \\
\hline 28 & $\mathrm{C} 1 / \mathrm{S}$ & 25.1 & 2320 \\
29 & $\mathrm{C} 2 / \mathrm{F}$ & 25.9 & 2329 \\
30 & $\mathrm{~S} 1 / 100$ & 24.7 & 2320 \\
31 & $\mathrm{~S} 2 / 75$ & 24.9 & 2367 \\
35 & $\mathrm{~S} 3 / 50$ & 25.4 & 2344 \\
36 & $\mathrm{~F} 1 / 100$ & 25.7 & 2329 \\
37 & $\mathrm{~F} 2 / 75$ & 25.0 & 2347 \\
38 & $\mathrm{~F} 3 / 50$ & 26.9 & 2335 \\
42 & $\mathrm{R} 1 / \mathrm{DR}$ & 26.7 & 2367 \\
43 & $\mathrm{R} 2 / \mathrm{GI}$ & 26.2 & 2320 \\
44 & $\mathrm{R} 3 \mathrm{DS}$ & 25.8 & 2373 \\
\hline
\end{tabular}

${ }^{a}$ One $150 \mathrm{~mm}$ concrete cube was tested on the day that the beam specimen was tested to represent its concrete strength.

\section{TABLE 4. EXPERIMENTAL RESULT OF TENSILE STRENGTH}

\begin{tabular}{|c|c|c|c|c|}
\hline \multirow[t]{2}{*}{ Bar type } & \multicolumn{3}{|c|}{$\begin{array}{l}\text { Tensile strength, } \\
f_{s, u} \text { or } f_{s l, u}\left(\mathrm{~N} / \mathrm{mm}^{2}\right)\end{array}$} & \multirow[t]{2}{*}{$\begin{array}{c}\text { Average strength, } \\
f_{s, u, a v g} \text { or } f_{s l, u, a v g}\left(\mathrm{~N} / \mathrm{mm}^{2}\right)\end{array}$} \\
\hline & Sample 1 & Sample 2 & Sample 3 & \\
\hline High yield steel bar & 532 & 551 & 547 & 543 \\
\hline Mild steel bar & 295 & 281 & 278 & 285 \\
\hline
\end{tabular}

Test results:

Table 5 presents the test results. The observed results comprised (a) the loads when the shear and flexural cracks were first detected, and (b) the load when the cracks first reached the opening. These results were obtained from the markings made to demonstrate the propagation of cracks during the test (Fig. 4).

TABLE 5. TEST RESULTS

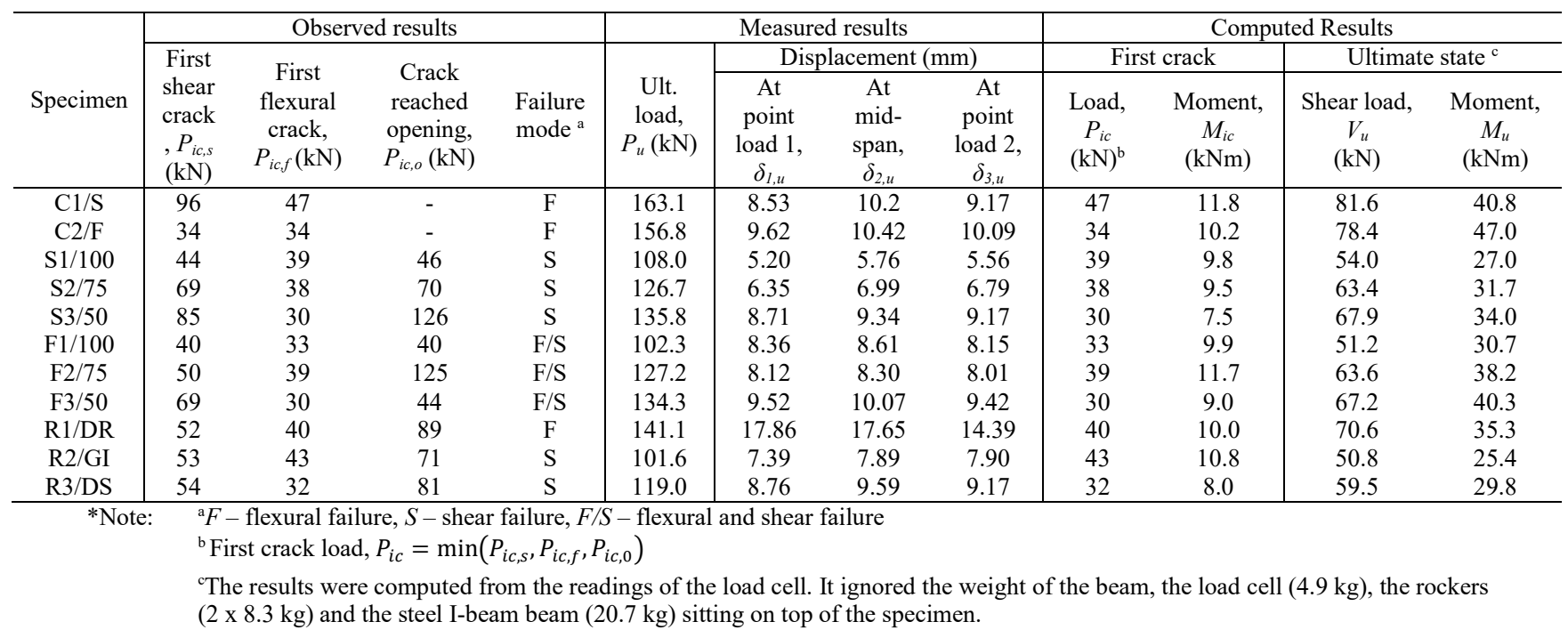


The measured results were the ultimate load and the beam displacement, which were obtained directly from the load cell and the LVDTs. The computed results were the calculated bending moment and shear load based on the load applied to the specimen (refer to (1) and (2)).

$$
\begin{aligned}
& V=\frac{P}{2} \\
& M=\frac{P a}{2}
\end{aligned}
$$

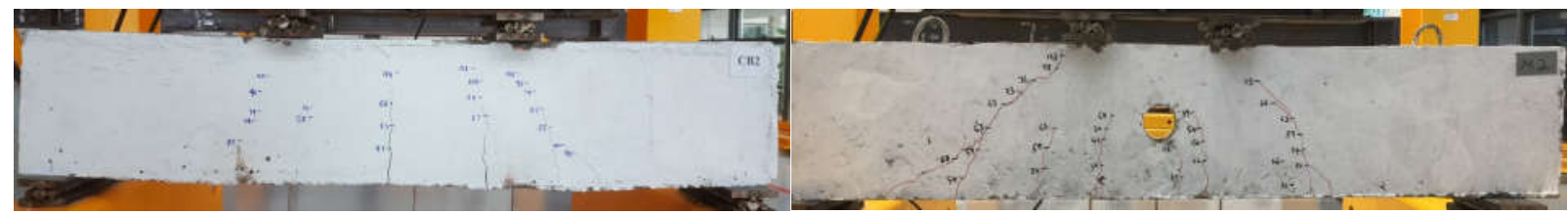

(a) Specimen $\mathrm{C} 1 / \mathrm{S}$

(g) Specimen F2/75



(b) Specimen $\mathrm{C} 2 / \mathrm{F}$

(h) Specimen F3/50



(c) Specimen S1/100

(i) Specimen R1/DR

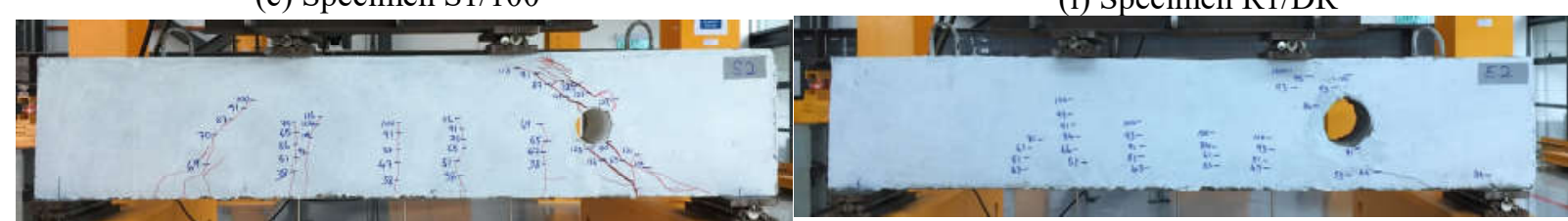

(d) Specimen S2/75

(j) Specimen R2/GI



(e) Specimen S3/50

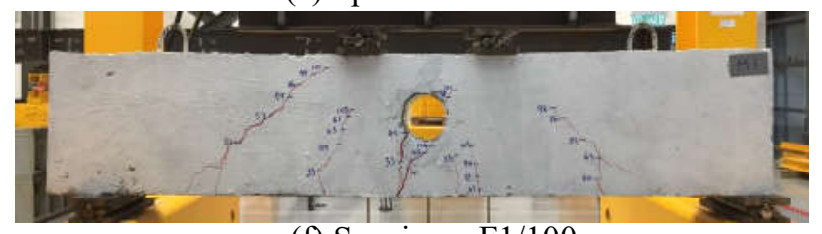

(k) Specimen R3/DS

(f) Specimen F1/100

Fig. 4: Crack pattern of test specimens

From Table 5:

a. The first crack was always the flexural crack. The load, $P_{i c, f}$, was always lower than $P_{i c, s}$ and $P_{i c, o}$.

b. As the opening size decreased from $100 \mathrm{~mm}$ to $50 \mathrm{~mm}$, (Table 6)

i. $\quad$ The first shear crack delayed ( $P_{i c, s}$ increased).

ii. The shear crack reaching the opening delayed ( $P_{i c, o}$ increased). No delay was noticed under the flexural load.

iii. The ultimate capacity of the beam, $P_{u}$, increased.

iv. The ultimate midspan displacement, $\delta_{2, u}$, increased. It developed at a faster rate when the opening was placed at the support.

c. The first flexural crack occurred at about the same time (about $9.6 \mathrm{kNm}$ moment load) regardless of the size, location, and reinforcement of the opening. 
J. H. Ling, H. S. Tang, W. K. Leong, H. T. Sia

TABLE 6. RESPONSE OF BEAM WHEN THE OPENING SIZE REDUCED FROM 100 MM TO 50 MM (WITHOUT REINFORCEMENT AT THE OPENING)

\begin{tabular}{|c|c|c|}
\hline \multirow{2}{*}{ Response } & \multicolumn{2}{|c|}{ Location of the opening } \\
\hline & Near the support & At midspan \\
\hline $\begin{array}{l}\text { The occurrence of the first } \\
\text { shear crack }\end{array}$ & $\begin{array}{l}\text { Delayed from } 44 \mathrm{kN} \text { to } 85 \mathrm{kN} \text { load, } P_{i c, s}(93 \% \\
\text { load increment) }\end{array}$ & $\begin{array}{l}\text { Delayed from } 40 \mathrm{kN} \text { to } 69 \mathrm{kN} \text { load, } P_{i c, s}(73 \% \text { load } \\
\text { increment). }\end{array}$ \\
\hline $\begin{array}{l}\text { The occurrence of the first } \\
\text { flexural crack }\end{array}$ & $\begin{array}{l}\text { About the same time. } \\
\text { Occurred around } 8.9 \mathrm{kNm} \text { average moment. }\end{array}$ & $\begin{array}{l}\text { About the same time. } \\
\text { Occurred around } 10.2 \mathrm{kNm} \text { average moment. }\end{array}$ \\
\hline $\begin{array}{l}\text { Crack first reaching the } \\
\text { opening }\end{array}$ & $\begin{array}{l}\text { Delayed from } 46 \mathrm{kN} \text { to } 126 \mathrm{kN} \text { load, } P_{i c, o}(274 \% \\
\text { load increment). }\end{array}$ & $\begin{array}{l}\text { No specific trend. } \\
\text { Depended on the propagation path of the crack. }\end{array}$ \\
\hline $\begin{array}{l}\text { The ultimate capacity of } \\
\text { the beam }\end{array}$ & $\begin{array}{l}\text { Increased by } 26 \% \text { (from } 108.0 \mathrm{kN} \text { to } 135.8 \mathrm{kN} \\
\text { ultimate load, } P_{u} \text { ) }\end{array}$ & $\begin{array}{l}\text { Increased by } 31 \% \text { (from } 102.3 \mathrm{kNm} \text { to } 134.3 \mathrm{kNm} \\
\text { moment) }\end{array}$ \\
\hline Deflection of beam & $\begin{array}{l}\text { Increased by } 60 \% \text { (from } 5.76 \mathrm{~mm} \text { to } 9.34 \mathrm{~mm} \text {, } \\
\delta_{2, u} \text { ) }\end{array}$ & $\begin{array}{l}\text { Increased slightly } 17 \% \text { (from } 8.61 \mathrm{~mm} \text { to } 10.07 \mathrm{~mm} \text {, } \\
\delta_{2, u} \text { ) }\end{array}$ \\
\hline
\end{tabular}

The reinforcements at the opening led to: (Table7)

a. An increase of the load to initiate the shear crack, $P_{i c, s}$, by $20 \%$.

b. A substantial increase in the load for the crack to reach the opening (54\% to $93 \%$ increment of $\left.P_{i c, o}\right)$.

The diagonal bar reinforcing method (specimen R1/DR) had effectively strengthened the beam with opening. It controlled the propagation of cracks surrounding the opening and increased the beam strength by $30 \%$. The G.I. reinforcing method was not effective. It did not increase the beam strength.

TABLE 7. COMPARISON OF DIFFERENT REINFORCEMENT METHOD WITH RESPECT TO THE BEAM WITH UNREINFORCED OPENINGS

\begin{tabular}{|c|c|c|c|}
\hline \multirow[t]{2}{*}{ Response } & \multicolumn{3}{|c|}{ Reinforcement methods } \\
\hline & Diagonal bar reinforcement & G.I. pipe reinforcement & Diagonal square reinforcement \\
\hline Load to initiate the shear crack, $P_{i c, s}$ & \multicolumn{3}{|c|}{$\begin{array}{c}\text { Similar for all methods } \\
\text { About } 20 \% \text { higher }\left(44 \mathrm{kN} \text { to } 53 \mathrm{kN} \text { average } P_{i c, s}\right)\end{array}$} \\
\hline Load to initiate the flexural crack, $P_{i c, f}$ & \multicolumn{3}{|c|}{ No specific trend. } \\
\hline $\begin{array}{l}\text { Load for the shear crack to first reach } \\
\text { the opening, } P_{i c, o}\end{array}$ & $\begin{array}{c}\text { Increased by } 93 \% \text { (from } 46 \mathrm{kN} \\
\text { to } 89 \mathrm{kN} \text { ) }\end{array}$ & $\begin{array}{l}\text { Increased by } 54 \% \\
\text { (from } 46 \mathrm{kN} \text { to } 71 \mathrm{kN} \text { ) }\end{array}$ & $\begin{array}{c}\text { Increased by } 76 \% \\
\text { (from } 46 \mathrm{kN} \text { to } 81 \mathrm{kN} \text { ) }\end{array}$ \\
\hline Ultimate load capacity, $P_{u}$ & $\begin{array}{c}\text { Increased by } 30 \% \text { (from } 108.0 \\
\mathrm{kN} \text { to } 141.1 \mathrm{kN})\end{array}$ & No notable effect & $\begin{array}{c}\text { Increased by } 10 \% \\
\text { (from } 108.0 \mathrm{kN} \text { to } 119.0 \mathrm{kN} \text { ) }\end{array}$ \\
\hline
\end{tabular}

\section{Load-Displacement Response:}

The load-displacement $(P-\delta)$ responses of the specimens are presented in Fig. 5. In general, the beam with opening behaved alike the solid beam, except it had lower stiffness, yield strength, ultimate strength, and ductility.

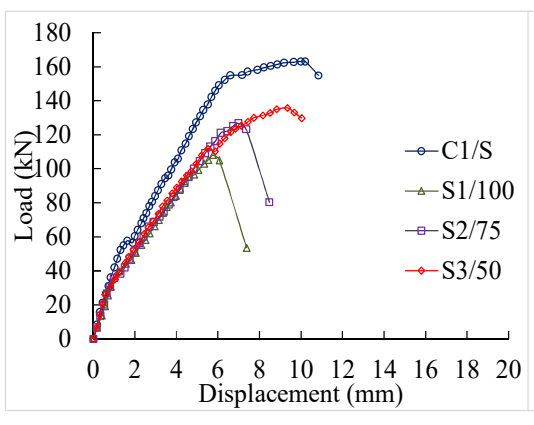

(a) Specimen $\mathrm{C} 1 / \mathrm{S}, \mathrm{S} 1 / 100, \mathrm{~S} 2 / 75$ and $\mathrm{S} 3 / 50$

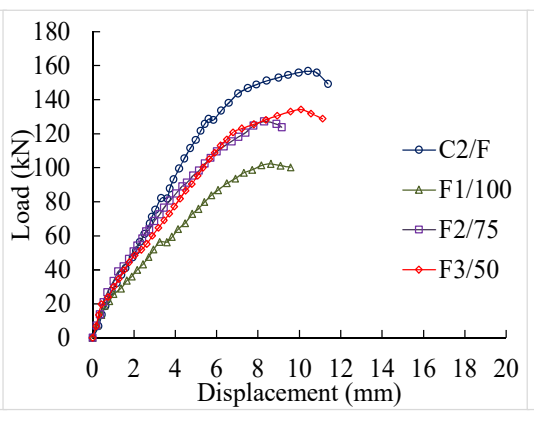

(b) Specimen C2/F, F1/100, F2/75 and $\mathrm{F} 3 / 50$



(c) Specimen R1/DR, R2/GI and $\mathrm{R} 3 / \mathrm{DS}$

Fig. 5: Load-displacement response

The beam typically initiated with a high degree of stiffness, as represented by the gradient of the $P-\delta$ curve. While the beam was in the elastic stage, small deflection developed proportionally to the applied load.

As the first crack developed, the stiffness decreased slightly. The flexural crack developed at the beam midspan from its soffit as the deformability limit of the concrete was exceeded. As the load increased, (a) the cracks extended and widened, (b) more cracks were observed, and (c) the cracking regions expanded sideways until a diagonal shear crack developed.

The progressive development of the cracks gradually degraded the beam stiffness. This led to a faster rate of beam deflection. Then, the beam yielded due to excessive cracking of concrete or excessive deformation of the tension bars. As the tension bars lost bonding with concrete, the deflection accelerated and the stiffness dropped drastically. The beam continued to deteriorate until the critical damage occurred. By then, the beam strength peaked and the ultimate state was reached. 
Without opening reinforcement, most beams failed almost immediately after the yield point. These beams were generally less ductile than a solid beam. The diagonal reinforcement bars in specimen R1/DR prolonged the postyielding stage of the beam for better ductility. The G. I. pipe and the diagonal square reinforcing methods (R2/GI and R3/DS) showed no notable effects on the ductility of the beam.

The beam properties were then computed from the $P-\delta$ curves, as demonstrated in Fig. 6 and given in Table VIII. The ultimate capacity, $P_{u}$, was the highest point of the curve. The corresponding displacement was the total displacement, $\delta_{u}$.

The yield point was determined based on the method used by Park (1988) [57] and Noushini et. al (2014) [58]. Two horizontal lines were drawn at $P_{u}$ and $0.75 P_{u}$. A straight line connecting the Origin and the interception of $0.75 P_{u}$ line and the $P-\delta$ curve was extended and intercepted with line $P_{u}$. The line gradient represented the secant stiffness, $E$, and the point on the $P-\delta$ curve below the interception was taken as the yield point $\left(P_{y}, \delta_{y}\right)$.

The beam properties were then re-computed into several ratios to indicate beam performance (Table VIII). These ratios reflected (a) the occurrence of the first cracks with respect to the yielding and ultimate strengths (i.e. $P_{i c} / P_{y}$, $P_{i c} / P_{u}, P_{i c, o} / P_{y}$ and $\left.P_{c i, o} / P_{u}\right)$, (b) the yield strength relative to the ultimate strength (i.e. $P_{y} / P_{u}$ ), and (c) the ductility of the specimens (i.e. $\delta_{u} / \delta_{y}$ ).

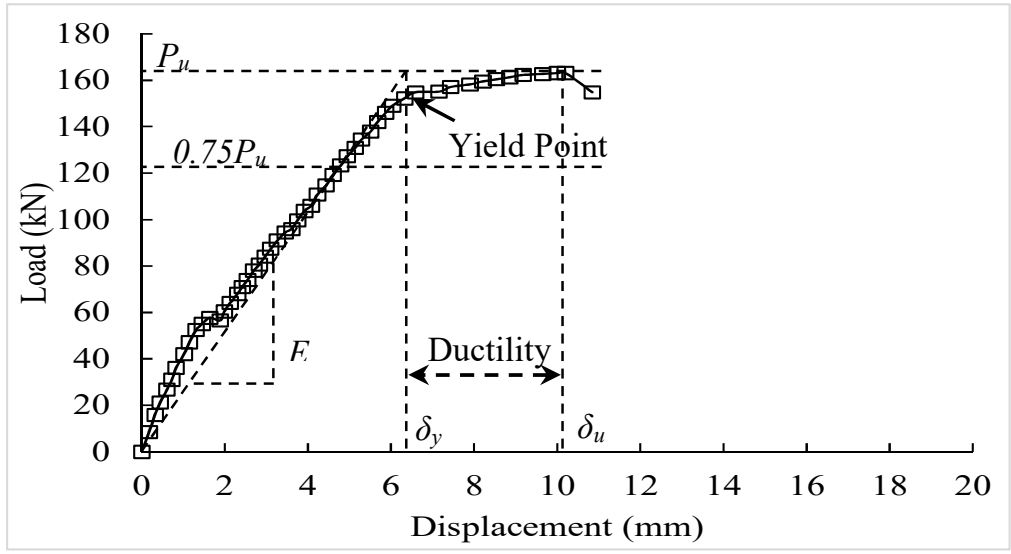

Fig. 6: Beam properties of a typical load-displacement response

TABLE 8. PROPERTIES AND PERFORMANCE RATIOS OF BEAM SPECIMENS

\begin{tabular}{|c|c|c|c|c|c|c|c|c|c|}
\hline \multirow{2}{*}{ Specimen } & \multirow{2}{*}{$\begin{array}{c}\text { Secant } \\
\text { stiffness, } E \\
(\mathrm{kN} / \mathrm{mm})\end{array}$} & \multirow{2}{*}{$\begin{array}{c}\text { Yield } \\
\text { strength, } P_{y} \\
\quad(\mathrm{kN})\end{array}$} & \multirow{2}{*}{$\begin{array}{c}\text { Yield } \\
\text { Displacement, } \\
\delta_{y}(\mathrm{~mm})\end{array}$} & \multicolumn{6}{|c|}{ Performance ratios } \\
\hline & & & & $P_{i d} / P_{y}$ & $P_{i c} / P_{u}$ & $P_{i c, o} / P_{y}$ & $P_{c i, o} / P_{u}$ & $P_{y} / P_{u}$ & $\delta_{u} / \delta_{y}$ \\
\hline $\mathrm{C} 1 / \mathrm{S}$ & 25.8 & 152.2 & 6.32 & 0.31 & 0.29 & - & - & 0.93 & 1.61 \\
\hline $\mathrm{C} 2 / \mathrm{F}$ & 23.3 & 140.0 & 6.73 & 0.24 & 0.22 & - & - & 0.89 & 1.55 \\
\hline $\mathrm{S} 1 / 100$ & 21.4 & 99.1 & 5.05 & 0.39 & 0.36 & 0.46 & 0.43 & 0.92 & 1.14 \\
\hline $\mathrm{S} 2 / 75$ & 20.7 & 120.7 & 6.12 & 0.31 & 0.30 & 0.58 & 0.55 & 0.95 & 1.14 \\
\hline $\mathrm{S} 3 / 50$ & 20.8 & 120.7 & 6.53 & 0.25 & 0.22 & 1.04 & 0.93 & 0.89 & 1.43 \\
\hline $\mathrm{F} 1 / 100$ & 14.8 & 93.8 & 6.91 & 0.35 & 0.32 & 0.43 & 0.39 & 0.92 & 1.25 \\
\hline $\mathrm{F} 2 / 75$ & 19.6 & 113.7 & 6.49 & 0.34 & 0.31 & 1.10 & 0.98 & 0.89 & 1.28 \\
\hline $\mathrm{F} 3 / 50$ & 18.7 & 122.9 & 7.18 & 0.24 & 0.22 & 0.36 & 0.33 & 0.92 & 1.40 \\
\hline $\mathrm{R} 1 / \mathrm{DR}$ & 23.2 & 123.1 & 6.08 & 0.32 & 0.28 & 0.72 & 0.63 & 0.87 & 2.90 \\
\hline $\mathrm{R} 2 / \mathrm{GI}$ & 16.5 & 94.0 & 6.16 & 0.46 & 0.42 & 0.76 & 0.70 & 0.93 & 1.28 \\
\hline R3/DS & 18.5 & 105.8 & 6.43 & 0.30 & 0.27 & 0.77 & 0.68 & 0.89 & 1.49 \\
\hline
\end{tabular}

Table 8 shows that:

a. The opening affected the beam stiffness more significantly when it is placed at the midspan, where the moment was predominant.

b. The occurrence of the first crack was not notably affected by the opening. It occurred around 0.24 to 0.39 times $P_{y}$ or 0.22 to 0.36 times $P_{u}$.

c. Depending on the pathway of the first crack, it reached the opening at various load levels $\left(0.36-1.10 P_{y}\right.$ or 0.33 $0.98 P_{u}$ ). If the opening was not in the way of the crack, $P_{i c, o}$ would be higher, as demonstrated by specimens $\mathrm{F} 2 / 75$ and $\mathrm{S} 3 / 50$.

d. The opening reinforcements controlled the propagation of the cracks, and thus, considerably increased the $P_{i c, o} / P_{y}$ and $P_{i c, o} / P_{u}$ ratios of the specimens.

e. The yield strength, $P_{y}$, was about $89 \%$ to $95 \%$ of the ultimate capacity, $P_{u}$. Should the ultimate capacity of the beams with an opening are analytically predicted, the design strength could be conservatively taken as 0.85 times the ultimate capacity.

f. The ductility ratio of the beam, $\delta_{u} / \delta_{y}$, was generally low. It barely exceeded 1.43 . It increased to 2.9 as the diagonal reinforcement bars were provided. 
From these observations, the following principles could be extracted:

a. For the beam to remain uncracked, the load should not exceed $1 / 4 P_{y}$ or $1 / 5 P_{u}$.

b. For a higher beam capacity, the opening should avoid the beam midspan and the support, where the maximum moment and shear occurs. It should also avoid the potential pathway of the first crack and the critical shear crack. Thus, the opening could be placed somewhere between the midspan and the shear crack (Fig. 7), subjected to verification in future studies.

c. Diagonal bars can be adopted to reinforce the beam with opening. The bars should be arranged perpendicularly to the diagonal cracks.

d. The opening size should not exceed 0.25 times the beam's height. The relevant beams (S2/75 and S3/50) are more likely to escape the pathway of the first crack.

\section{Failure Modes:}

From Fig. 4, the critical causes of failure were identified based on the severity of the cracks, as defined from the concentration of crack lines and the crack width. Specimens S1/100, S2/75 and S3/50 implied the shear failure. There were shear cracks propagated diagonally from the support, passing through the opening, and to the point load (Fig. 4(c), (d) and (e)). The crack width was larger than the flexural cracks at the midspan.

Specimens F1/100, F2/75 and F3/50 demonstrated a combined shear and flexural failure (Fig. 4(f), (g) and (h)). The flexural cracks occurred at the midspan, propagated upward, and passed through the opening and to the top surface of the beam. Meanwhile, shear cracks developed diagonally from the support to the point load. Their crack widths were similar.

In the presence of the opening, the shear cracks were generally more severe (Fig. 4(c), (d) and (e)). It created void in the beam, reduced the effective cross-sectional area, led to the concentration of stress surrounding it, and thus, the beam failed earlier.

With the diagonal reinforcements (specimen R1/DR), the severity of the shear cracks reduced (Fig 4(i)). The reinforcements had effectively controlled the diagonal cracks and subsequently strengthened the beam. The G. I. pipe reinforcing method (specimen R2/GI) failed to control the shear cracks (Fig. 4(j)). The high compressive strength of the opening did not strengthen the beam at all. The diagonal square reinforcement (specimen R3/DS) slightly delayed the beam failure by disrupting the propagation of the first shear crack. However, the next diagonal crack, which developed at an offset distance from the first crack, bypassed the reinforcement and resulted in the beam failure (Fig. 4(k)). For that, the reinforcement should cover a wider beam region.

\section{Deflection:}

The deflection profiles of the beams are shown in Fig. 8. For the symmetrical load setup, the largest deflection always occurred at the midspan.

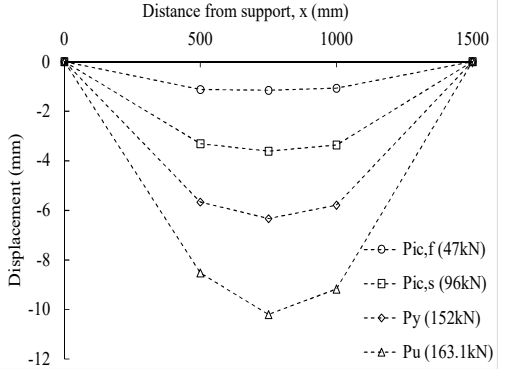

(a) $\mathrm{C} 1 / \mathrm{S}$

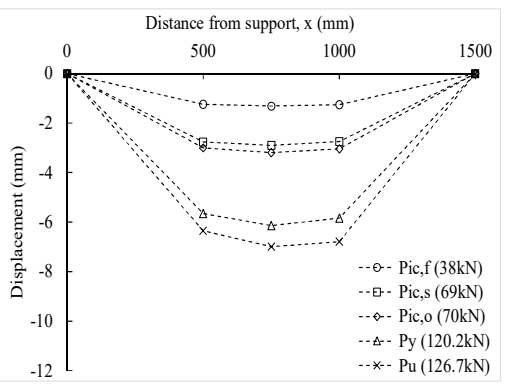

(d) $\mathrm{S} 2 / 75$



(b) $\mathrm{C} 2 / \mathrm{F}$

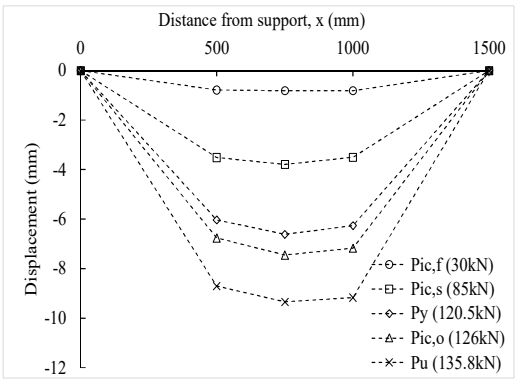

(e) $\mathrm{S} 3 / 50$

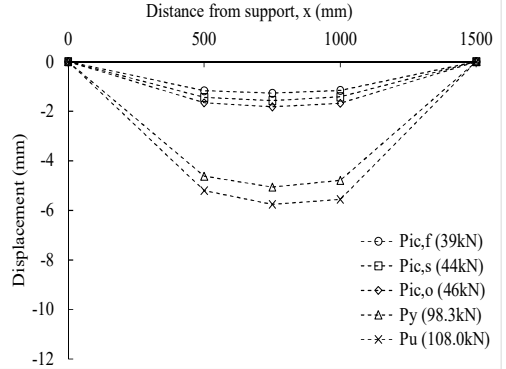

(c) $\mathrm{S} 1 / 100$

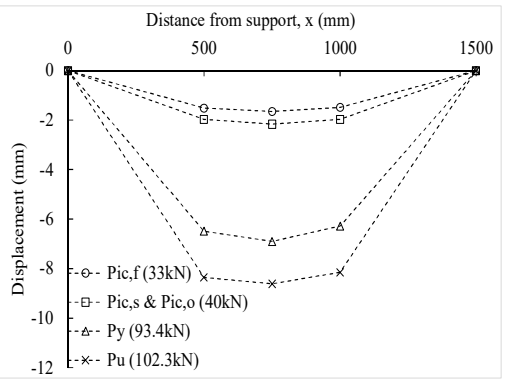

(f) $F 1 / 100$

Fig. 8: Deflection profile 


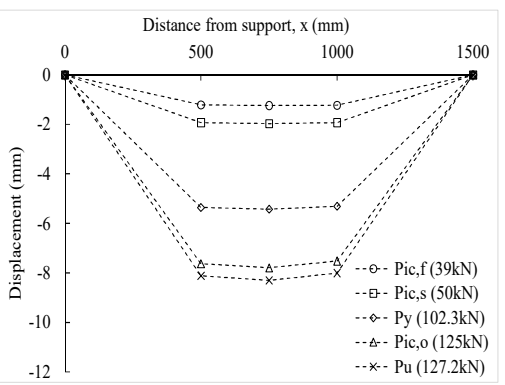

(g) F2/75

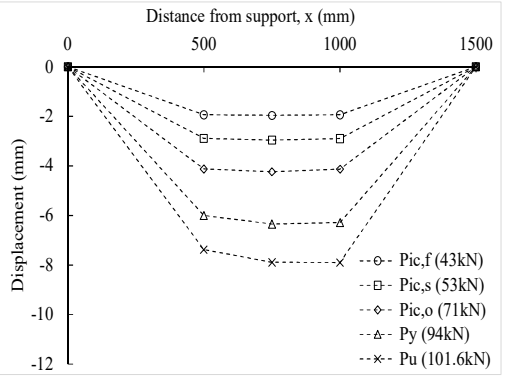

(j) R2/GI

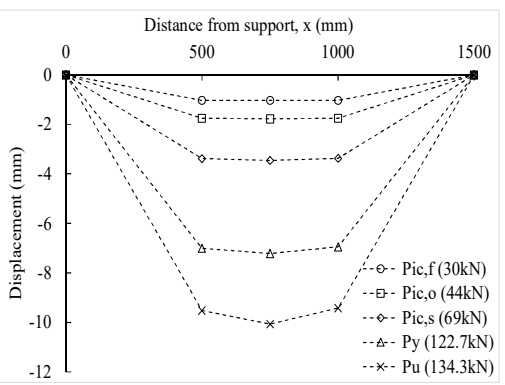

(h) F3/50

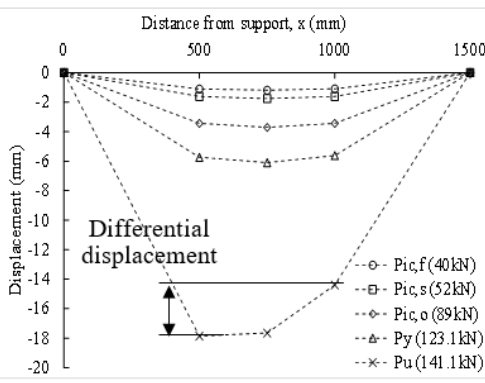

(i) R1/DR

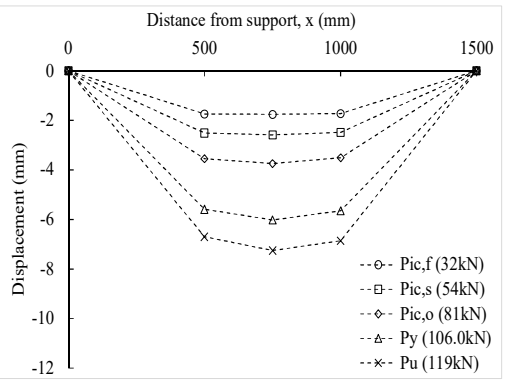

(k) R3/DS

Fig. 8: Deflection profile (cont)

In general, the deflection profile remained symmetrical prior to the occurrence of the first shear crack $\left(\delta_{1} \approx\right.$ $\left.\delta_{3}\right)$. Then, the differences between the two displacements increased gradually when a diagonal crack propagated at one side of the beam. The beam side with the opening normally had a larger shear crack, therefore, a larger deflection occurred. When the opening was placed at the midspan, the shear cracks at both sides of the beam were similar.

\section{Effects of opening to RC beam:}

The beams with opening are compared with the control specimens $\mathrm{C} 1 / \mathrm{S}$ and $\mathrm{C} 2 / \mathrm{F}$ in Table 9 . The parametric responses are demonstrated in Fig. 9.

TABLE 9. PERFORMANCE OF BEAM RELATIVE TO CONTROL SPECIMENS

\begin{tabular}{|c|c|c|c|c|c|c|c|}
\hline & Specimen & $\begin{array}{l}\text { Stiffness } \\
\qquad E_{i} / E_{c}\end{array}$ & $\begin{array}{c}\text { Yield } \\
\text { strength } \\
P_{y, i} / P_{y, c}\end{array}$ & $\begin{array}{l}\text { Ultimate } \\
\text { strength } \\
P_{u, i} / P_{u, c} \\
\end{array}$ & $\begin{array}{c}\text { Yielding } \\
\text { displacement } \\
\delta_{y, i} / \delta_{y, c}\end{array}$ & $\begin{array}{c}\text { Ultimate } \\
\text { displacement } \\
\delta_{u, i} / \delta_{u, c}\end{array}$ & $\begin{array}{l}\text { Ductility } \\
\qquad \Delta_{i} / \Delta_{c}\end{array}$ \\
\hline \multirow{4}{*}{$\begin{array}{l}\text { Effects of transverse opening near } \\
\text { the support }\end{array}$} & $\mathrm{C} 1 / \mathrm{S}$ & 1.00 & 1.00 & 1.00 & 1.00 & 1.00 & 1.00 \\
\hline & $\mathrm{S} 1 / 100$ & 0.83 & 0.65 & 0.66 & 0.80 & 0.56 & 0.71 \\
\hline & $\mathrm{S} 2 / 75$ & 0.80 & 0.79 & 0.78 & 0.97 & 0.69 & 0.71 \\
\hline & $\mathrm{S} 3 / 50$ & 0.81 & 0.79 & 0.83 & 1.03 & 0.92 & 0.89 \\
\hline \multirow{4}{*}{$\begin{array}{l}\text { Effects of transverse opening at } \\
\text { midspan }\end{array}$} & $\mathrm{C} 2 / \mathrm{F}$ & 1.00 & 1.00 & 1.00 & 1.00 & 1.00 & 1.00 \\
\hline & $\mathrm{F} 1 / 100$ & 0.64 & 0.67 & 0.65 & 1.03 & 0.83 & 0.81 \\
\hline & $\mathrm{F} 2 / 75$ & 0.84 & 0.81 & 0.81 & 0.96 & 0.80 & 0.83 \\
\hline & $\mathrm{F} 3 / 50$ & 0.80 & 0.88 & 0.86 & 1.07 & 0.97 & 0.9 \\
\hline \multirow{4}{*}{$\begin{array}{l}\text { Effects of reinforcement for } \\
\text { transverse opening under shear load }\end{array}$} & $\mathrm{S} 1 / 100$ & 1.00 & 1.00 & 1.00 & 1.00 & 1.00 & 1.00 \\
\hline & $\mathrm{R} 1 / \mathrm{DR}$ & 1.08 & 1.24 & 1.31 & 1.20 & 3.06 & 2.54 \\
\hline & $\mathrm{R} 2 / \mathrm{GI}$ & 0.77 & 0.95 & 0.94 & 1.22 & 1.37 & 1.12 \\
\hline & $\mathrm{R} 3 / \mathrm{DS}$ & 0.86 & 1.07 & 1.10 & 1.27 & 1.66 & 1.31 \\
\hline
\end{tabular}

It is observed that:

a. The opening affected the stiffness, yield strength, ultimate strength, and the ductility of the beam, regardless of the position whether at the midspan or the support. Such detrimental effects were more pronounced as the opening size increased.

b. The increasing opening size at the support affected the beam ductility more significantly than the midspan.

c. The stiffness was significantly affected by a large opening at the midspan. The opening size of $1 / 3 h$ affected $36 \%$ of stiffness, as demonstrated by specimen F1/100.

d. The reduction of beam strength was about proportion to the opening size. The beam lost approximately $1 / 3$ of its strength when the opening size reached $1 / 3$ of beam height. It lost $1 / 6$ of the strength as the opening size was $1 / 6 h$.

e. To maintain at least $80 \%$ beam performance, the opening size should not exceed $0.25 h$. 


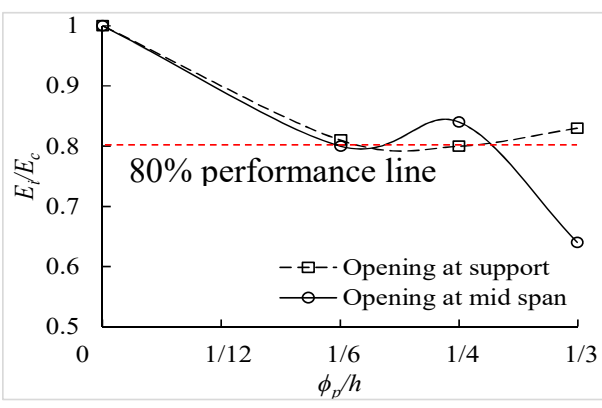

(a) Stiffness

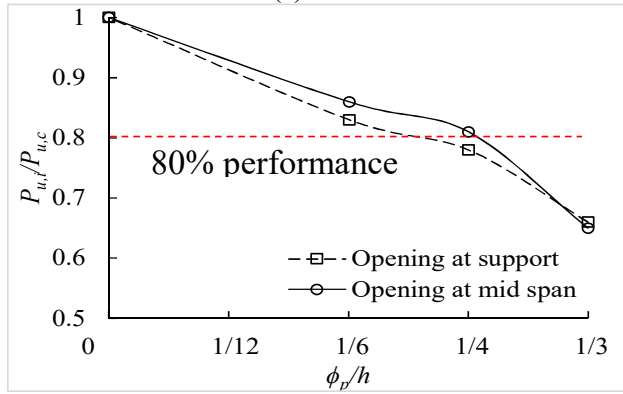

(c) Ultimate strength



(b) Yield strength

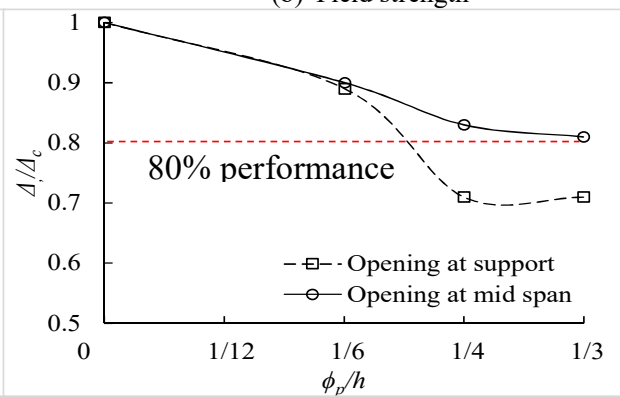

(d) Ductility

Fig. 9: Effects of opening size on beam properties

The comparison of the reinforcing methods shows that (Table 9):

a. The diagonal bar reinforcing method (R1/DR) was the most effective of all. It increased stiffness, yield strength, ultimate strength and ductility by $8 \%, 24 \%, 31 \%$, and $154 \%$ respectively.

b. The G.I. pipe reinforcing method (R2/GI) did not strengthen the beam in any way.

c. The diagonal square reinforcing method (R3/DS) was less effective than the diagonal bar reinforcing method. It only increased by $10 \%$ of the ultimate strength compared with a $31 \%$ increase by the diagonal bar reinforcing method.

\section{Predicting the ultimate capacity:}

For predicting the ultimate capacity of the beam with opening, the equation model proposed by Mansur and Tan (1999) [51] was tested. The model was modified from ACI-318 [56] and was popularly referred by the researchers $[3,5,35,43,47,49,54,59]$, with or without modifications.

The nominal shear strength of the beam is the sum of the shear strength given by the concrete, $V_{c}$, the shear reinforcement, $V_{s l}$, and the diagonal reinforcement, $V_{s d}(3)$.

$$
\begin{gathered}
V_{n}=V_{c}+V_{s l}+V_{s d} \\
\text { where } \quad V_{c}=\frac{1}{6} \sqrt{f_{c}} b\left(d-d_{o}\right) \\
V_{s l}=\frac{A_{s l} f_{y, s l}}{s}\left(d_{v}-d_{o}\right) \\
V_{s d}=A_{d} f_{y, d} \sin \alpha
\end{gathered}
$$
[51].

The nominal flexural strength of the beam is derived from the stress block diagram in Fig. 10, as given in (7)

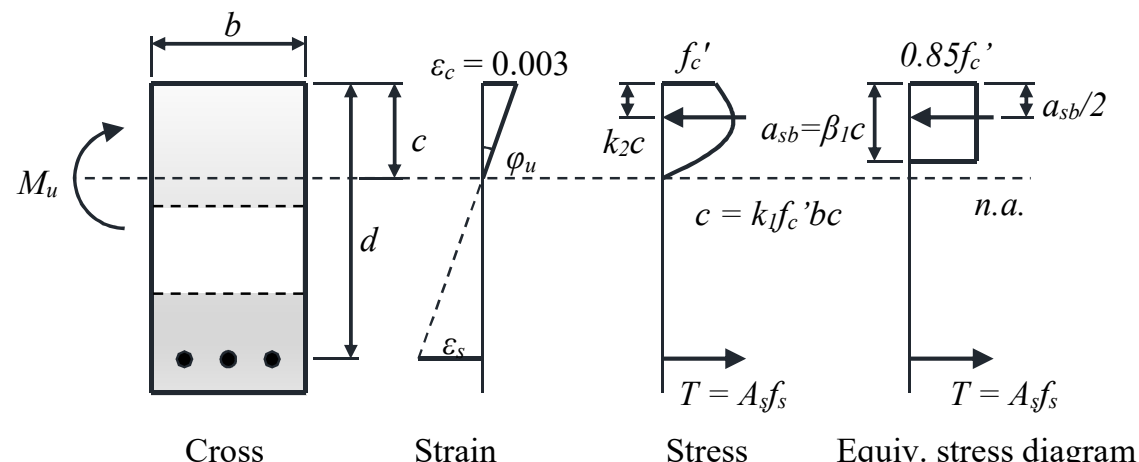

Fig. 10: Stress diagram by Mansur and Tan (1999) 


$$
\begin{aligned}
& M_{n}=A_{s} f_{y, b}\left(d-\frac{a_{s b}}{2}\right) \\
& \text { where } \quad a_{s b}=\frac{A_{s} f_{y, b}}{0.85 f_{c} b}
\end{aligned}
$$

The nominal shear and flexural strengths are converted into functions of the equivalent load acting on the beam based on the experimental setup of this study, as expressed in (9) and (10).

$$
\begin{aligned}
& P_{u, v}=2 V_{n} \\
& P_{u, M}=\frac{2 M_{n}}{a}
\end{aligned}
$$

The ultimate strength of the beam is theoretically governed by the smaller value of the nominal shear or flexural strength (11).

$$
P_{u, p r e}=\min \left\{P_{u, V}, P_{u, M}\right\}
$$

To determine the reliability of the equation model, the data from the experiments were substituted into the equations. For predicting the ultimate strength of beam, the ultimate stresses of concrete and steel bars, $f_{c, u}, f_{s, u, a v g}$ and $f_{s l, u, a v g}$, were used to substitute $f_{c}, f_{y, b}, f_{y, s l}, f_{y, d}$ in (4) to (8), as demonstrated in Table 10.

The predicted load capacities of the beams, $P_{u, p r e}$, were then compared with the load capacities of the experiment, $P_{u, \exp }$ in Table XI. The equation model was found not reliable in predicting the loading capacity of the

\begin{tabular}{|c|c|c|c|c|c|c|c|c|c|}
\hline \multirow[b]{2}{*}{ Specimen } & \multicolumn{4}{|c|}{ Computing data } & \multicolumn{3}{|c|}{ Shear strength } & \multicolumn{2}{|c|}{ Beam Capacity } \\
\hline & $\begin{array}{c}\text { Concrete } \\
\text { strength, } f_{c} \\
\left(\mathrm{~N} / \mathrm{mm}^{2}\right)^{\text {a }} \\
\end{array}$ & $\begin{array}{l}\text { Opening } \\
\text { diameter, } \\
d_{o}(\mathrm{~mm}) \\
\end{array}$ & $\begin{array}{c}\text { Spacing of } \\
\text { shear links, } \\
s(\mathrm{~mm})\end{array}$ & $\begin{array}{l}\text { Area of opening } \\
\text { reinforcement, } \\
A_{d}\left(\mathrm{~mm}^{2}\right)\end{array}$ & $\begin{array}{c}\text { Concrete, } \\
V_{c}(\mathrm{kN})\end{array}$ & $\begin{array}{c}\text { Shear } \\
\text { reinforcement, } \\
V_{s l}(\mathrm{kN}) \\
\end{array}$ & $\begin{array}{c}\text { Diagonal } \\
\text { reinforcement, } \\
V_{s d}(\mathrm{kN}) \\
\end{array}$ & $\begin{array}{c}\text { Shear } \\
\text { capacity, } \\
V_{n}(\mathrm{kN}) \\
\end{array}$ & $\begin{array}{c}\text { Moment } \\
\text { capacity, } \\
M_{n}(\mathrm{kNm}) \\
\end{array}$ \\
\hline Eq. & & & & & (4) & (5) & (6) & (3) & (7) \\
\hline $\mathrm{C} 1 / \mathrm{S}$ & 20.1 & 0 & 250 & 0 & 29.3 & 25.7 & 0 & 55 & 29.1 \\
\hline $\mathrm{C} 2 / \mathrm{F}$ & 21.0 & 0 & 150 & 0 & 29.9 & 42.8 & 0 & 72.7 & 29.2 \\
\hline $\mathrm{S} 1 / 100$ & 19.7 & 100 & 250 & 0 & 17.9 & 14.2 & 0 & 32.1 & 29 \\
\hline $\mathrm{S} 2 / 75$ & 19.9 & 75 & 250 & 0 & 20.7 & 17 & 0 & 37.7 & 29.1 \\
\hline $\mathrm{S} 3 / 50$ & 20.4 & 50 & 250 & 0 & 23.8 & 19.9 & 0 & 43.7 & 29.1 \\
\hline $\mathrm{F} 1 / 100$ & 20.8 & 100 & 150 & 0 & 18.4 & 23.6 & 0 & 42 & 29.2 \\
\hline $\mathrm{F} 2 / 75$ & 20.0 & 75 & 150 & 0 & 20.8 & 28.4 & 0 & 49.2 & 29.1 \\
\hline $\mathrm{F} 3 / 50$ & 22.0 & 50 & 150 & 0 & 24.7 & 33.2 & 0 & 57.9 & 29.3 \\
\hline R1/DR & 21.8 & 100 & 250 & 226 & 18.8 & 14.2 & 86.8 & 119.8 & 29.3 \\
\hline $\mathrm{R} 2 / \mathrm{GI}$ & 21.3 & 100 & 250 & 0 & 18.6 & 14.2 & 0 & 32.8 & 29.3 \\
\hline R3DS & 20.9 & 100 & 250 & 226 & 18.4 & 14.2 & 86.8 & 119.4 & 29.2 \\
\hline
\end{tabular}
beam;

a. Only 1 out of 11 specimens had the reliability ratios, $R_{r}$, within the acceptable range of 0.9 to 1.1 .

b. Only $55 \%$ of the predict failure mode was as per the failure mode observed in the test.

TABLE 10. COMPUTATION OF THE MOMENT AND SHEAR STRENGTHS OF BEAM SPECIMEN

*Note: $\quad{ }^{\mathrm{a}} \mathrm{f}_{\mathrm{c}}=$ compressive strength of cylinder, which was computed through a correlation between the strength of concrete

\begin{tabular}{|c|c|c|c|c|c|c|c|c|c|}
\hline \multirow[b]{2}{*}{ Specimen } & \multicolumn{6}{|c|}{ Load capacity } & \multicolumn{3}{|c|}{ Failure mode } \\
\hline & $\begin{array}{c}\text { Due to } \\
\text { shear, } \\
P_{u, v}(\mathrm{kN})\end{array}$ & $\begin{array}{c}\text { Due to } \\
\text { moment, } \\
P_{u, M}(\mathrm{kN})\end{array}$ & $\begin{array}{c}\text { Prediction, } \\
P_{u, p r e}(\mathrm{kN})\end{array}$ & $\begin{array}{c}\text { Experiment, } \\
P_{u, \exp }(\mathrm{kN})\end{array}$ & $\begin{array}{l}\text { Reliability } \\
\text { ratio, } R_{r}= \\
P_{u, p r e} / P_{u, e x p}\end{array}$ & Remarks $^{\text {a }}$ & Prediction ${ }^{\mathrm{b}}$ & Experiment & Remarks $^{\mathrm{c}}$ \\
\hline $\mathrm{C} 1 / \mathrm{S}$ & 110.0 & 116.4 & 110 & 163.1 & 0.67 & NA & $\mathrm{S}$ & $\mathrm{F}$ & NA \\
\hline $\mathrm{C} 2 / \mathrm{F}$ & 145.4 & 97.4 & 97.4 & 156.8 & 0.62 & NA & F & $\mathrm{F}$ & A \\
\hline $\mathrm{S} 1 / 100$ & 64.2 & 116.1 & 64.2 & 108.0 & 0.59 & NA & S & S & A \\
\hline $\mathrm{S} 2 / 75$ & 75.4 & 116.2 & 75.4 & 126.7 & 0.60 & NA & S & S & A \\
\hline $\mathrm{S} 3 / 50$ & 87.4 & 116.5 & 87.4 & 135.8 & 0.64 & NA & S & S & A \\
\hline $\mathrm{F} 1 / 100$ & 84.0 & 97.3 & 84.0 & 102.3 & 0.82 & NA & S & $\mathrm{F} / \mathrm{S}$ & NA \\
\hline $\mathrm{F} 2 / 75$ & 98.4 & 96.9 & 96.9 & 127.2 & 0.76 & NA & $\mathrm{F}$ & $\mathrm{F} / \mathrm{S}$ & NA \\
\hline $\mathrm{F} 3 / 50$ & 115.8 & 97.8 & 97.8 & 134.3 & 0.73 & NA & $\mathrm{F}$ & $\mathrm{F} / \mathrm{S}$ & NA \\
\hline $\mathrm{R} 1 / \mathrm{DR}$ & 239.6 & 117.3 & 117.3 & 141.1 & 0.83 & NA & $\mathrm{F}$ & $\mathrm{F}$ & A \\
\hline $\mathrm{R} 2 / \mathrm{GI}$ & 65.6 & 117.0 & 65.6 & 101.6 & 0.65 & NA & S & S & A \\
\hline R3DS & 238.8 & 116.8 & 116.8 & 119.0 & 0.98 & $\mathrm{~A}$ & $\mathrm{~F}$ & $\mathrm{~S}$ & NA \\
\hline Reliability $^{\mathrm{d}}$ & & & & & & $1 / 11$ & & & $6 / 11$ \\
\hline Note: & $\begin{array}{l}\text { eliabl } \\
\text { Flexu } \\
\text { redic } \\
\text { aber o }\end{array}$ & $\begin{array}{l}\text { diction ( } \\
\text { ilure (w } \\
\text { ilure mo } \\
\text { licable } \mathrm{p}\end{array}$ & $\begin{array}{l}\leq R_{n} \leq 1 \\
P_{u, M}<P \\
=\text { experi } \\
\text { iction ou }\end{array}$ & $\begin{array}{l}\mathrm{NA}-\mathrm{un} \\
\mathrm{S}-\mathrm{She} \\
\text { tal failur } \\
\text { the total }\end{array}$ & $\begin{array}{l}\text { predic } \\
\text { re (wh } \\
\text { NA - }\end{array}$ & $\begin{array}{l}\left(R_{n}<0\right. \\
u, V<P_{u} \\
\text { dicted fa }\end{array}$ & $\begin{array}{l}\left.R_{n}>1.1\right) \\
\text { mode } \neq \text { ex }\end{array}$ & iv & 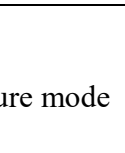 \\
\hline
\end{tabular}
cube and cylinder based on the standard concrete grade in Eurocode 2, C20/25, C25/30, C30/37.

${ }^{\mathrm{b}}$ Computing data: $b=150 \mathrm{~mm}, d=261 \mathrm{~mm}, A_{s l}=101 \mathrm{~mm}^{2}, f_{y, s l}=f_{s l, u, a v g}=285 \mathrm{~N} / \mathrm{mm}^{2}, d_{v}=223 \mathrm{~mm}, f_{y, b}=f_{y, d}=$ $f_{s, u, \text { avg }}=543 \mathrm{~N} / \mathrm{mm}^{2}, \alpha=45^{\circ}=0.785 \mathrm{rad} ., A_{s}=226 \mathrm{~mm}^{2}$

TABLE 11. RELIABILITY OF THE PREDICTED LOAD CAPACITY AND FAILURE MODE OF BEAM WITH RESPECT TO EXPERIMENTAL RESULTS 
From Table 11:

a. The predicted results were consistently lower than the experimental results. The reliability ratios, $R_{r}$, were always less than 1.0. Thus, the equation model gave conservative estimations of the strength of the beams with opening.

b. The equation model is less accurate in predicting the responses of (i) the solid beams (specimens $\mathrm{C} 1 / \mathrm{S}$ and $\mathrm{C} 2 / \mathrm{F}$ ), and (ii) the beams that failed in shear (specimens S1/100, S2/75, S3/50, and R2/GI).

c. The model predicted the beam to be governed by the shear strength when (i) the opening was placed at the support (specimens $\mathrm{S} 1 / 100, \mathrm{~S} 2 / 75$, and $\mathrm{S} 3 / 50$ ), (ii) large-diameter opening $(\geq 1 / 3 h)$ be placed at the midspan without proper reinforcements (specimens F1/100 and R2/GI).

\section{CONCLUSION}

This study was carried out to investigate the effects of opening on beam performance. Based on the experimental results, the following conclusions can be drawn:

a. The opening affected the beam performance in terms of stiffness, yield strength, ultimate strength, and ductility, particularly for large the opening size.

b. For a marginal strength reduction $(\leq 20 \%)$, the opening size should not exceed 0.25 times the beam height.

c. The diagonal bar reinforcing method was effective in reinforcing the beams with the opening of $1 / 3$ beam height.

The equation model proposed by Mansur and Tan (1999) [51] predicted the ultimate capacity of the beam with opening conservatively. The predicted values were generally lower than the experimental results.

\section{ACKNOWLEDGMENT}

This work was supported by the Research Grants of University College of Technology Sarawak, UCTS/RESEARCH/2/2018/02.

\section{SYMBOLS}

a Distance between point load and support, $\mathrm{mm}$

$a_{s b} \quad$ Depth of equivalent rectangular stress block, mm

$b \quad$ Width of beam, mm

d Effective beam depth, mm

$d_{o} \quad$ Diameter of transverse opening, $\mathrm{mm}$

$d_{v} \quad$ Centre-to-centre distance between the top and bottom steel bar, $\mathrm{mm}$

$f_{c} \quad$ Compressive strength of concrete, $\mathrm{N} / \mathrm{mm}^{2}$

$f_{c, u} \quad$ Ultimate compressive stress of concrete cube, $\mathrm{N} / \mathrm{mm}^{2}$

$f_{s, u} \quad$ Ultimate tensile stress of top and bottom steel bar, $\mathrm{N} / \mathrm{mm}^{2}$

$f_{s l, u} \quad$ Ultimate tensile stress of shear link, $\mathrm{N} / \mathrm{mm}^{2}$

$f_{s, u, a v g} \quad$ Average value of ultimate tensile stress of top and bottom steel bar, $\mathrm{N} / \mathrm{mm}^{2}$

$f_{s l, u, a v g} \quad$ Average value of ultimate tensile stress of shear link, $\mathrm{N} / \mathrm{mm}^{2}$

$f_{y, b} \quad$ Specified yield strength of bottom steel bar, $\mathrm{N} / \mathrm{mm}^{2}$

$f_{y, d} \quad$ Specified yield strength of diagonal steel, $\mathrm{N} / \mathrm{mm}^{2}$

$f_{y, s l} \quad$ Specified yield strength of shear links, N/mm 2

$h \quad$ Height of beam, mm

$l \quad$ Clear span of beam between support, $\mathrm{mm}$

$s \quad$ Spacing of shear links, mm

$t_{o} \quad$ Thickness of opening pipe, mm

$x \quad$ Distance between transverse opening and support, $\mathrm{mm}$

$A_{d} \quad$ Area of diagonal reinforcement, $\mathrm{mm}$

$A_{s} \quad$ Area of bottom steel bar, $\mathrm{mm}^{2}$

$A_{s l} \quad$ Area of shear link, mm

E Stiffness of beam, $\mathrm{kN} / \mathrm{mm}$

$E_{c} \quad$ Stiffness of control specimen, $\mathrm{kN} / \mathrm{m}$

$E_{i} \quad$ Stiffness of the respective test specimens, $\mathrm{kN} / \mathrm{m}$

$M \quad$ Moment, $\mathrm{kNm}$

$M_{i c} \quad$ Moment when the first flexural crack occurred, $\mathrm{kNm}$

$M_{n} \quad$ Nominal flexural strength, $\mathrm{kNm}$

$M_{u} \quad$ Moment at ultimate state, $\mathrm{kNm}$

$P \quad$ Point load generated by hydraulic cylinder acting on beam, $\mathrm{kN}$

$P_{i c} \quad$ Applied load when the first crack initiated, $\mathrm{kN}$

$P_{i c, f} \quad$ Applied load when flexural crack initiated, $\mathrm{kN}$

$P_{i c, o} \quad$ Applied load when crack reached the transverse opening, $\mathrm{kN}$

$P_{i c, s} \quad$ Applied load when shear crack initiated, $\mathrm{kN}$ 
$P_{y} \quad$ Applied load when the beam yielded, $\mathrm{kN}$

$P_{y, c} \quad$ Yielding load of control specimen, $\mathrm{kN}$

$P_{y, i} \quad$ Yielding load of respective specimen, $\mathrm{kN}$

$P_{u} \quad$ Ultimate load generated by hydraulic cylinder acting on beam, $\mathrm{kN}$

$P_{u, c} \quad$ Ultimate load of control specimen, $\mathrm{kN}$

$P_{u, \exp } \quad$ Load capacity of beam obtained from experiment, $\mathrm{kN}$

$P_{u, p r e} \quad$ Predicted load capacity of beam based on equation model, $\mathrm{kN}$

$P_{u, i} \quad$ Ultimate load of respective test specimen, $\mathrm{kN}$

$R_{r} \quad$ Reliability ratio

$V \quad$ Shear load, $\mathrm{kN}$

$V_{c} \quad$ Shear strength of beam due to the concrete, $\mathrm{kN}$

$V_{i c} \quad$ Shear load when the first shear crack occurred, $\mathrm{kN}$

$V_{s d} \quad$ Shear strength of beam due to diagonal reinforcement, $\mathrm{kN}$

$V_{s l} \quad$ Shear strength of beam due to the shear reinforcement, $\mathrm{kN}$

$V_{u} \quad$ Shear load at ultimate state, $\mathrm{kN}$

$V_{n} \quad$ Nominal shear strength, $\mathrm{kN}$

$\alpha \quad$ Angle of inclination of diagonal bars, rad.

$\delta_{u} \quad$ Vertical displacement of beam at midspan at ultimate state, $\mathrm{mm}$

$\delta_{u, c} \quad$ Ultimate displacement of control specimen, $\mathrm{mm}$

$\delta_{u, i} \quad$ Ultimate displacement of respective specimen, $\mathrm{mm}$

$\delta_{y} \quad$ Vertical displacement of beam at midspan at yielding state, $\mathrm{mm}$

$\delta_{y, c} \quad$ Displacement at yield point of control specimen, $\mathrm{mm}$

$\delta_{y, i} \quad$ Displacement at yield point of respective specimen, $\mathrm{mm}$

$\delta_{1} \quad$ Vertical displacement of beam at midspan, $\mathrm{mm}$

$\delta_{2} \quad$ Vertical displacement of beam at below the point load no. 1, mm

$\delta_{3} \quad$ Vertical displacement of beam at below the point load no. 2, mm

$\delta_{1, u} \quad$ Vertical displacement of beam at midspan at ultimate state, $\mathrm{mm}$

$\delta_{2, u} \quad$ Vertical displacement of beam at below the point load no. 1 at ultimate state, $\mathrm{mm}$

$\delta_{3, u} \quad$ Vertical displacement of beam at below the point load no. 2 at ultimate state, $\mathrm{mm}$

$\rho_{c} \quad$ Density of concrete, $\mathrm{kg} / \mathrm{m}^{3}$

$\Delta_{c} \quad$ Ductility of control specimen

$\Delta_{i} \quad$ Ductility of respective specimen

\section{REFERENCES}

[1] S. C. Chin, N. Shafiq, and M. F. Nuruddin, "Strengthening of RC beams containing large opening at flexure with CFRP laminates", World Academy of Science and Technology, vol. 60, pp. 12-25, 2011.

[2] L. Herrera, S. Anacleto-Lupianez, and A. Lemnitzer, "Experimental performance of RC moment frame beams with rectangular openings", Engineering Structures, vol. 152, pp. 149-167, 2017.

[3] A. Ahmed, M. M. Fayyadh, S. Naganathan, and K. Nasharuddin, "Reinforced concrete beams with web openings: A state of the art review", Materials \& Design, vol. 40, pp. 90-102, 2012.

[4] S. C. Chin, N. Shafiq, and M. F. Nuruddin, "FRP as strengthening material for reinforced concrete beams with openings - A review", KSCE Journal of Civil Engineering, vol. 19(1), pp. 213-219, 2015.

[5] B. H. Osman, E. Wu, B. Ji, and A. M. S. Abdelgader, "A state of the art review on reinforced concrete beams with openings retrofitted with FRP”, International Journal of Advanced Structural Engineering, vol. 8(3), pp. 253-267, 2016.

[6] K. J. Jithinbose, J. Thomas, and N. B. Parappattu, "Effect of openings in beams - a review", International Journal of Innovative Research in Advanced Engineering (IJIRAE), vol. 3(9), pp. 15-19, 2016.

[7] M. S. Latha, and B. M. Naveen Kumar, "Behavior of reinforced concrete beam with opening", International Journal of Civil Engineering and Technology (IJCIET) 8(7) (2017) 581-593.

[8] A. El-kareim Shoeib, and A. El-sayed Sedawy, "Shear strength reduction due to introduced opening in loaded RC beams", Journal of Building Engineering, vol. 13, pp. 28-40, 2017.

[9] S. B. Kudatini, and H. Eramma, "Experimental investigation on internally strengthened RC beam with rectangular web opening", International Journal of Innovative Research in Science, Engineering and Technology, vol. 5(8), pp. 15410-15417, 2016.

[10] S. Amiri, and R. Masoudnia, "Investigation of the opening effects on the behavior of concrete beams without additional reinforcement in opening region using fem method", Australian Journal of Basic and Applied Sciences, vol. 5(5), 617-627, 2011.

[11] R. B. Hafiz, S. Ahmed, S. Barua, and S. Chowdhury, "Effects of opening on the behavior of reinforced concrete beam", IOSR Journal of Mechanical and Civil Engineering (IOSR-JMCE), vol. 11(2), pp. 52-61, 2014.

[12] N. H. Saksena, and P. G. patel, "Experimental study of reinforced concrete beam with web openings", International Journal of Advanced Engineering Research and Studies, vol. 2(3), pp. 66-68, 2013.

[13] S. Amiri, R. Masoudnia, and A. Akbar Pabarja, "The study of the effects of web openings on the concrete beams", Australian Journal of Basic and Applied Sciences, vol. 5(7), 547-556, 2011.

[14] J. H. Ling, H. S. Tang, W. K. Leong, and H. T. Sia, "Effects of transverse circular opening in reinforced concrete beam subjected to incremental static load", Borneo Journal of Sciences and Technology, vol. 1(2), pg 16-26, 2019. 
[15] M. Tariq, "Shear behaviour of rc deep beams with openings strengthened with carbon fiber reinforced polymer", Internation Scholarly and Scientific Research \& Innovation, vol. 11(8), pp. 1138-1143, 2017.

[16] S. Chutani, and D. Joshi, "Evaluation of ultimate strength of reinforced concrete deep beams with web openings", International Journal of Research in Engineering and Social Sciences (IJRESS), vol. 7(5), pp. 19-25, 2016.

[17] A. R. Mohamed, M. S. Shoukry, and J. M. Saeed, "Prediction of the behavior of reinforced concrete deep beams with web openings using the finite element method", Alexandria Engineering Journal, vol. 53(2), pp. 329-339, 2014.

[18] T. M. Yoo, J. H. Doh, H. Guan, and S. Fragomeni, "Experimental behaviour of high-strength concrete deep beams with web openings", The Structural Design of Tall and Special Buildings 22(8), pp. 655-676, 2013.

[19] R. A. Hawileh, T. A. El-Maaddawy, and M. Z. Naser, "Nonlinear finite element modeling of concrete deep beams with openings strengthened with externally-bonded composites", Materials \& Design, vol. 42, pp. 378-387, 2012.

[20] G. Campione, and G. Minafò, "Behaviour of concrete deep beams with openings and low shear span-to-depth ratio", Engineering Structures, vol. 41, pp. 294-306, 2012.

[21] H. Guan, and J. H. Doh, "Development of strut-and-tie models in deep beams with web openings", Advances in Structural Engineering, vol. 10(6), pp. 697-711, 2007.

[22] K. H. Yang, H. C. Eun, and H. S. Chung, "The influence of web openings on the structural behavior of reinforced high-strength concrete deep beams", Engineering Structures, vol. 28(13), pp. 1825-1834, 2006.

[23] H. C. Eun, Y. H. Lee, H. S. Chung, and K. H. Yang, "On the shear strength of reinforced concrete deep beam with web opening", The Structural Design of Tall and Special Buildings, vol. 15(4), pp. 445-466, 2006.

[24] H. Guan, "Strut-and-tie model of deep beams with web openings - an optimisation approach", Structural Engineering and Mechanics, vol. 19(4), pp. 361-379, 2005.

[25] N. E. Shanmugam, and S. Swaddiwudhipong, "Strength of fibre reinforced concrete deep beams containing openings", International Journal of Cement Composites and Lightweight Concrete, vol. 10(1), pp. 53-60, 1988.

[26] M. A. Mansur, and W. A. M. Alwis, "Reinforced fibre concrete deep beams with web openings", International Journal of Cement Composites and Lightweight Concrete, vol. 6(4), pp. 263-271, 1984.

[27] F. K. Kong, G. R. Sharp, S. C. Appleton, C. J. Beaumont, and L. A. Kubik, "Structural idealization for deep beams with web openings: further evidence", Magazine of Concrete Research, vol. 30(103), pp. 89-95, 1978.

[28] J. A. Saeed, and A. R. Yousif, "Tests of fibrous and nonfibrous reinforced concrete continuous deep beams with web openings", Journal of Zankoy Sulaimani, vol. 15(2), vol. 1-20, 2013.

[29] J. K. Lee, C. G. Li, Y. T. Lee, "Experimental study on shear strength of reinforced concrete continuous deep beams with web opening", 14th World Conference on Earthquake Engineering, Beijing, China, 2008.

[30] L. Herrera, and A. Lemnitzer, "Cyclic performance of rc beams with web openings", 2nd European Conference on Earthquake Engineering and Seismology, Istanbul, 2014.

[31] N. K. Oukaili, and A. H. Al-Shammari, "CFRP Strengthening of RC beams with multiple openings subjected to static and impact loads", Advances in Structural Engineering, vol. 17(12), pp. 1747-1760, 2014.

[32] J. Tanijaya, "Shear stress distribution in the opening chords of hybrid r/c t-beams with opening", MATEC Web Conf., vol. 147, pp. 01005, 2018.

[33] A. E. Salama, M. E. Kassem, and A. A. Mahmoud, "Torsional behavior of T- shaped reinforced concrete beams with large web openings", Journal of Building Engineering, vol. 18, 84-94, 2018.

[34] X. F. Nie, S. S. Zhang, J. G. Teng, and G. M. Chen, "Experimental study on RC T-section beams with an FRP-strengthened web opening", Composite Structures, vol. 185, pp. 273-285, 2018.

[35] S. Vuggumudi, "Experimental study on shear strengthening of RC T-beams with web openings using FRP composites", National Institute Of Technology, Rourkela, India, p. 122, 2013.

[36] M.A. Mansur, "Design of reinforced concrete beams with web openings", 6th Asia-Pacific Structural Engineering and Construction Conference (APSEC 2006), Kuala Lumpur, Malaysia, pp. 104-120, 2006.

[37] A. Yaser, and S. Hemzah, "Nonlinear analysis for behavior of RC horizontally curved ring beams with openings and strengthened by CFRP laminates", Jordan Journal of Civil Engineering, vol. 8(4) pp. 482-493, 2014.

[38] A. Yaser, and S. Hemzah, "Nonlinear analysis for behavior of R.C. horizontally semicircular curved beams with openings and strengthened by CFRP laminates", International Journal of Innovative Research in Advanced Engineering (IJIRAE), vol. 3(9), pp. 15$19,2014$.

[39] S.A. Hemzah, "Behavior of R. C. horizontally curved beams with openings strengthened by CFRP laminates", College of Engineering, Babylon University, Iraq, 2014.

[40] K. Fawzy, "Strengthening of opening R. C. beams in shear using bonded external reinforcements", International Journal of Engineering Science and Innovative Technology (IJESIT), vol. 4(2), pp. 11-23, 2015.

[41] S. A. Al-Sheikh, "Flexural behavior of RC beams with opening", Concrete Research Letters, vol. 5(2), pp. 812-824, 2014.

[42] A. M. Mahmoud, "Strengthening of concrete beams having shear zone openings using orthotropic CFRP modeling", Ain Shams Engineering Journal, vol. 3(3), pp. 177-190, 2012.

[43] J. Vaseghi Amiri, and M. Hosseinalibygie, "Effect of small circular opening on the shear and flextural behavior and ultimate strength of reinforced concrete beams using normal and high strength concrete, 13th World Conference on Earthquake Engineering (WCEE), Vancouver, B.C., Canada 2004.

[44] M.A. Mansur, "Effect of openings on the behaviour and strength of R/C beams in shear", Cement and Concrete Composites, vol. 20(6) pp. 477-486, 1998.

[45] S. R. R. Saripalli, "Study on torsional behaviour of retrofitted rectangular RC beams with web openings", India, National Institute of Technology, Rourkela, p. 46, 2015.

[46] M. Venugopal, "Behaviour of GFRP retrofitted rectangular RC beams with small web openings under torsion: experimental study", Department of Civil Engineering, National Institute of Technology, Rourkela, India, 2014.

[47] B. Aykac, I. Kalkan, S. Aykac, and Y. E. Egriboz, "Flexural behavior of RC beams with regular square or circular web openings", Engineering Structures, vol. 56, pp. 2165-2174, 2013. 
[48] S. Mamatha, N. Changler, P. Singore, S. S. Jevoora, and L. Geetha, "The study of behavior of RC beam with transverse opening under static load, International Journal of Engineering Science and Computing, vol. 7(6), pp. 13480-13484, 2017.

[49] B. H. Osman, E. Wu, B. Ji, and S.S. Abdulhameed, "Shear behavior of reinforced concrete (RC) beams with circular web openings without additional shear reinforcement", KSCE Journal of Civil Engineering, vol. 21(1), pp. 296-306, 2016.

[50] T. El Maaddawy, and S. Sherif, "FRP composites for shear strengthening of reinforced concrete deep beams with openings", Composite Structures, vol. 89(1), pp. 60-69, 2009.

[51] M. A. Mansur, K. H. Tan, "Concrete beams with openings: analysis and design”, Taylor \& Francis 1999.

[52] N. F. Somes, and W. G. Corley, "Circular openings in webs of continuous beams", Special Publication, vol. 42, 1974.

[53] M. R. Osman, K. Metwally, M. S. Wafaa, "Proposed recommendations for the design of reinforced concrete beams with openings", The 2015 World Congress on Advances in Structural Engineering and Mechanics (ASEM15), Incheon, Korea, 2015.

[54] H. Abdalla, A. M. Torkey, H. A. Haggag, A. F. Abu-Amira, "Design against cracking at openings in reinforced concrete beams strengthened with composite sheets", Composite Structures, vol. 60, pp. 197-204, 2003.

[55] E. G. Prentzas, "Behaviour and reinforcement of concrete beams with large rectangular apertures", University of Sheffield, 1968.

[56] ACI-318-14, "Building code requirements for structural concrete and commentary", American Concrete Institute Farmington Hills MI, 2014.

[57] R. Park, "Ductility evaluation from laboratory and analytical testing", The 9th World Conference on Earthquake Engineering, TokyoKyoto, Japan, pp. 605-616, 1988.

[58] A. Noushini, B. Samali, and K. Vessalas, "Performance of concrete beam elements reinforced with polyvinyl alcohol (PVA) micro fibres", Concrete in Australia, vol. 40(1), pp. 22-27, 2014.

[59] B. H. Osman, E. Wu, B. Ji, and S.S. Abdulhameed, "Repair of pre-cracked reinforced concrete (RC) beams with openings strengthened using FRP sheets under sustained load", International Journal of Concrete Structures and Materials, vol. 11(1), pp. 171-183, 2017. 
J. H. Ling, H. S. Tang, W. K. Leong, H. T. Sia 